\title{
In Vitro Antibacterial Activity of Flavonoid Extracts of Two Selected Libyan Algae against Multi-Drug Resistant Bacteria Isolated from Food Products
}

\author{
Rabia Alghazeer ${ }^{*}$, Abdalla Elmansori' ${ }^{2}$, Moammar Sidati ${ }^{3}$, Ftaim Gammoudi', Salah Azwai ${ }^{4}$, \\ Hesham Naas ${ }^{5}$, Aboubaker Garbaj ${ }^{5}$, Ibrahim Eldaghayes ${ }^{4}$ \\ ${ }^{1}$ Department of Chemistry, Faculty of Sciences, University of Tripoli, Tripoli, Libya \\ ${ }^{2}$ Department of Botany, Faculty of Sciences, University of Tripoli, Tripoli, Libya \\ ${ }^{3}$ Marin Biology Research Center, Tajura-East of Tripoli, Tripoli, Libya \\ ${ }^{4}$ Department of Microbiology and Parasitology, Faculty of Veterinary Medicine, University of Tripoli, Tripoli, Libya \\ ${ }^{5}$ Department of Food Hygiene and Control, Faculty of Veterinary Medicine, University of Tripoli, Tripoli, Libya \\ Email: ${ }^{*}$ Rabia_alghazeer@yahoo.com
}

How to cite this paper: Alghazeer, R., Elmansori, A., Sidati, M., Gammoudi, F., Azwai, S., Naas, H., Garbaj, A. and Eldaghayes, I. (2017) In Vitro Antibacterial Activity of Flavonoid Extracts of Two Selected Libyan Algae against Multi-Drug Resistant Bacteria Isolated from Food Products. Journal of Biosciences and Medicines, 5, 26-48. http://dx.doi.org/10.4236/jbm.2017.51003

Received: October 25, 2016

Accepted: January 2, 2017

Published: January 5, 2017

Copyright $\odot 2017$ by authors and Scientific Research Publishing Inc. This work is licensed under the Creative Commons Attribution International License (CC BY 4.0).

http://creativecommons.org/licenses/by/4.0/

\section{(c) (i) Open Access}

\begin{abstract}
This study aimed to evaluate the antibacterial activity of flavonoids extracted from two Libyan brown algae namely Cystoseira compressa and Padina pavonica using microwave-assisted extraction method against pathogenic bacteria isolated from meat, meat products, milk and dairy products (Staphylococcus aureus subsp. aureus (5 isolates), Bacillus cereus (3 isolates), Bacillus pumilus (1 isolate), Salmonella enterica subsp. enteric (4 isolates) and Enterohaemorrhagic Escherichia coli O157 (EHEC O157) (4 isolates)). All of these isolates were muti-drug resistant with high MAR index. The results showed that $C$. compressa extract exhibited better and stronger antibacterial activities against the seventeen tested isolates with inhibition zones diameter ranged from 14 $22 \mathrm{~mm}$ compared to $P$. pavonica extract which showed positive effect against 9 isolates with low inhibition zone ranged from $11-16.5 \mathrm{~mm}$. Flavonoids extracted from $C$. compressa also displayed the best spectrum of bactericidal effect with a ratio $\mathrm{MBC} / \mathrm{MIC} \leq 4$ obtained on all susceptible tested bacterial strains. Flavonoids and proanthocyanidins significantly contributed to the antibacterial properties. The mode of action of these active extracts is under investigation.
\end{abstract}

\section{Keywords}

Brown Algae, Flavonoids, Multi-Drug Resistant Bacteria, Antibacterial Activity 


\section{Introduction}

Seaweeds contain various bioactive metabolites which can benefit human health [1] [2]. They are currently in different phases of clinical trials [3] [4] due to their highly content of terpenes, alkaloids as well as phenolic compounds. The Phenolic compounds in algae are less reported than that in higher plants [5].

Although flavonoids are the most important polyphenolic compounds, few reports have paid attention to flavonoids from marine sources. The flavonoids are members of a class of natural compounds that recently have been the subject of considerable scientific and therapeutic interest. Flavonoids are known to contain a broad spectrum of chemicals and biological activities including antioxidant and free radical scavenging properties, antibacterial, antiviral, anticancer, anti-inflammatory, anti-allergic and also as potential therapeutic agents against a wide variety of diseases [6] [7] [8]. However on the basis of earlier reports, presence of flavonoids remained questionable in marine algae [9]. Evidence of flavonoid has only been reported from Acanthophora spicifera (Vahl) Børgesen [10] [11]. In 2009 Sabina and Aliya [12] had isolated Scutellarein 4'-methyl ether from red algae which was showed several bioactivity including anti-allergic [13], anticancer and anti-cytotoxic [14] activities in vitro and in vivo. Several extraction techniques and solvents are used for obtaining antioxidant and antibacterial agents from natural sources. Extraction techniques include solvent extraction (SE), soxhlet extraction, ultrasonication assisted extraction and supercritical fluid extraction [15] [16] [17]. Moreover, microwave assisted extraction (MAE), a new extraction method, has been introduced, in order to reduce the economic, environmental and durational costs of the extraction as well as to improve extraction yield [18] [19].

The importance of microbes to food products of animal origin had been demonstrated by recent outbreaks of food-borne illness associated with consumption of meat, milk and dairy products that had been contaminated with pathogenic organisms or toxins. Undesirable microorganisms constitute the primary hazard to safety, quality, and wholesomeness of food products. Recently there is urgent need to find new antibacterial agents due to the wide spread of drug-resistant bacteria [20]. These drug-resistant bacteria are increasing due to the resistivity that bacteria have developed and lack of new antimicrobials to combat them. Seaweeds have been proven to be a good source of antibacterial agents [21] [22] [23] [24].

As plants synthesized flavonoids as a response action to microbial infection; therefore it is expected that flavonoids are a good antimicrobial agent against various microorganisms. The antibacterial activity of flavonoids depends on the structures, namely on the substitutions on the aromatic rings. Antibacterial flavonoids might be having multiple cellular targets, rather than one specific site of action. One of their molecular actions is to form complex with proteins through nonspecific forces such as hydrogen bonding and hydrophobic effects, as well as by covalent bond formation. Thus, their mode of antimicrobial action may be related to their ability to inactivate microbial adhesion, enzymes, cell envelope 
transport proteins, and so forth. Lipophilic flavonoids may also disrupt microbial membranes [25] [26].

The objective of this study was to assess the antibacterial activity of flavonoids extracted from two Libyan brown algae using microwave-assisted extraction method against multi-drug resistant bacterial strains.

\section{Materials and Methods}

\subsection{Collection and Processing of Algal Samples}

Cystoseira compressa (C. compressa) and Padania pavonica (P. pavonica) were collected from western coast of Libya (SA1, N32 53.764 E13 20.990, SA 02, N32 53.756 E13 21.064; SA 03, N32 53.792 E13 21.070; SA 04, N32 53.804 E13 21.028; SA 05, N32 53.777 E13 20.983) between June and August 2015 (Figure 1). The algal samples were taxonomically identified at Marine plankton and algae department, Marine biology research center, Tajura-(east of Tripoli), Libya. Algae samples were cleaned by removing the epiphytes and necrotic parts. Samples were rinsed with sterile water and shade dried for 7 - 14 days and ground thoroughly to powder in a kitchen-type blender.

\subsection{Preliminary Phytochmical Tests}

Preliminary phytochmical tests for identification of alkaloids, anthraquinones, coumarins, flavonoids, saponins, tannins, and terpenes were carried out for all the extracts using standard qualitative methods that have been described previously [27].

\subsection{Microwave Assisted Extraction (MAE) of Flavonoid}

Experiments were carried out in a domestic (Black \& Decker, Model No. MZ

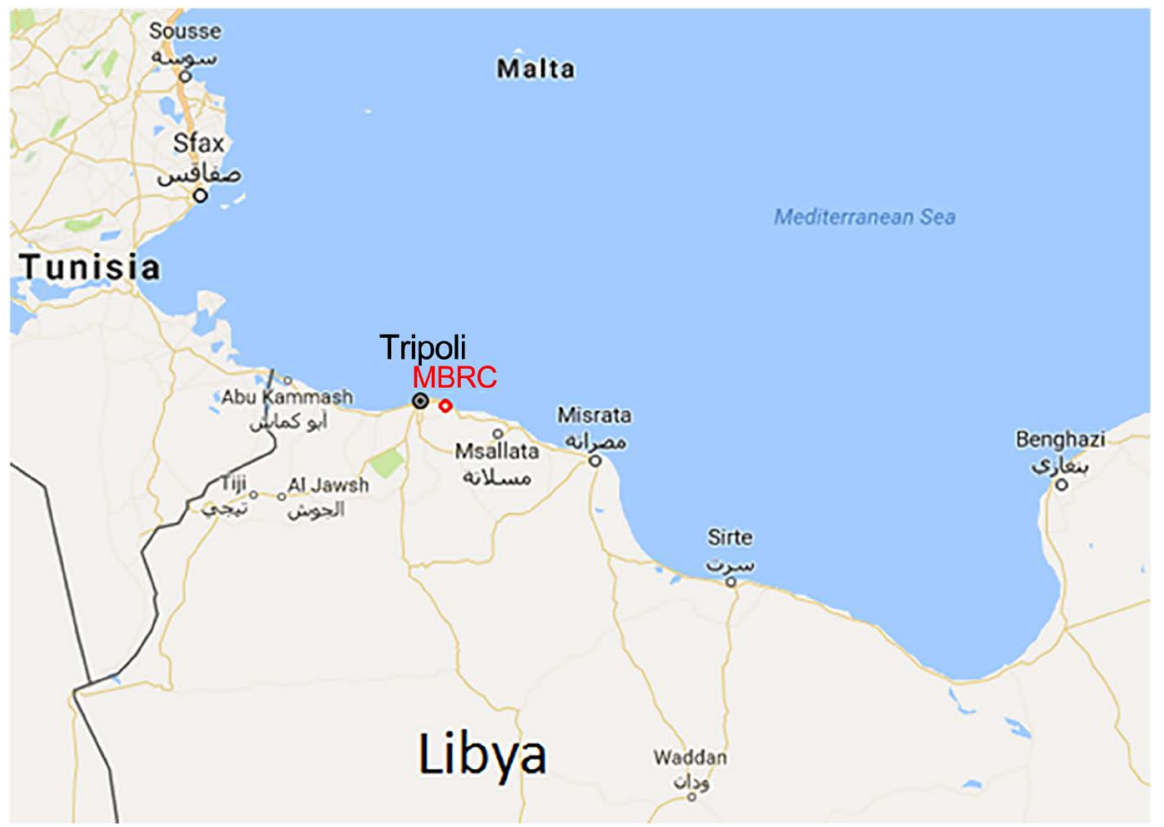

Figure 1. Localization of the collection site of algae. 
3000 PG, SL13YD, England) microwave oven system. Twenty five grams of the powdered plant materials were mixed with solvents (ethanol or methanol $80 \%$ ) at a suitable ratio $(500 \mathrm{ml})$. An intermittent microwave irradiation method was used to keep the temperature of the extraction mixtures below $80^{\circ} \mathrm{C}$ [28]. The suspension was radiated in microwave oven at regular intervals (30 sec radiation and $30 \mathrm{sec}$ off). Variation in irradiation time from one algae to another was dependent on the result of an assay-guided purification i.e. a quick flavonoids TLC spot test on the extraction products, using mobile phase 9:1 Benzene: Methanol Extraction was stopped when the spot test indicted maximum yield for the tested algae (data not shown). The infusions were allowed to cool down to room temperature, filtrated and stored at $\left(4^{\circ} \mathrm{C}\right)$ for further analysis.

\subsection{Antibacterial Activity Assay}

Antibacterial activity assay was accomplished in the Department of Microbiology and Parasitology, Faculty of Veterinary Medicine; and Biochemistry Lab, Chemistry Department, Faculty of Science, University of Tripoli, Libya.

\section{4.1. Isolation and Identification of Bacterial Isolates}

Standard microbiological methods [29] [30] were used to isolate 8 Gram negative (S. enterica 17 (Sal 1), S. enterica 18 (Sal 2), S. enterica 19 (Sal 3), S. enterica 29 (Sal 4), EHEC O157 57 (E1), EHEC O157 55 (E2), EHEC O157 52 (E3), EHEC O157 $49(\mathrm{E} 4)$ ) and, 9 Gram positive isolates (S. aureus $122(\mathrm{~S} 1)$, S. aureus 128 (S2), S. aureus 287 (S3), S. aureus 125 (S4); S aureus 283 (S5), B. cereus 4 (B1), B. cereus 16 (B2), B. cereus 72 (B3), B. pumilus 124 (B4)) from meat, meat products, milk and dairy products collected from different parts of Libya. All of the tested isolates were identified and characterized by culturing in the specific appropriate media followed by using conventional biochemical tests as well as partial sequencing of 16S rDNA as described by Azwai et al., 2016 [31].

\subsubsection{Standardization of Bacterial Suspension}

The bacterial suspensions were standardized following the CLSI guidelines for aerobic bacteria [32]. All of the tested bacteria were grown in Mueller Hinton Broth (MHB, Hi-Media) for 18 - $24 \mathrm{~h}$, followed by the matching of bacterial suspension to the turbidity equivalent to $0.5 \mathrm{McFarland}$ solution $\left(1.5 \times 10^{8} \mathrm{CFU} /\right.$ $\mathrm{mL}$ ) with the addition of sterile saline.

\subsubsection{Antibiotic Sensitivity Test}

Susceptibility against antimicrobials was performed against all of the above mentioned isolated bacterial strains by disk diffusion method according to standard microbiological protocol (National Committee for Clinical Laboratory Standards) [33] on Mueller-Hinton agar (Oxoid) using 24 of commonly used antibiotics; Amoxycillin (10 $\mu \mathrm{g}, \mathrm{AML})$, Amoxycillin/clavulanic acid (30 $\mu \mathrm{g}, \mathrm{AM}-\mathrm{C})$, Ampicillin $(10 \mu \mathrm{g}, \mathrm{AMP})$, Bacitracin $(10 \mu \mathrm{g}, \mathrm{B})$, Penicillin $(10 \mu \mathrm{g}, \mathrm{P})$, Methicillin $(5 \mu \mathrm{g}$, $\mathrm{ME})$, Erythromycin $(15 \mu \mathrm{g}, \mathrm{E})$, Gentamycin $(10 \mu \mathrm{g}, \mathrm{CN})$, Kanmycin $(30 \mu \mathrm{g}, \mathrm{K})$, Lincomycin (10 $\mu \mathrm{g}, \mathrm{MY})$, Tobramycin $(10 \mu \mathrm{g}$, TOB), Vancomycin (30 $\mu \mathrm{g}, \mathrm{VA})$, 
Levofloxacin (5 $\mu \mathrm{g}, \mathrm{LEV})$, Clindamycin (DA), Cefotaime (30 $\mu \mathrm{g}, \mathrm{CTX})$, Doxycycline (30 $\mu \mathrm{g}, \mathrm{DO})$, Ciprofloxacin (5 $\mu \mathrm{g}$, CIP), Cloxacillin (O B), Nitrofurantoin (F), Oxytetracyclin $(30 \mu \mathrm{g}, \mathrm{OT})$, Streptomycin $(30 \mu \mathrm{g}, \mathrm{S})$, Tetracycline (300 $\mu \mathrm{g}, \mathrm{TE})$, Chloramphenicol (30 $\mu \mathrm{g}, \mathrm{C})$, and Sulphamethoxazole/Tri-methoprim $(25 \mu \mathrm{g}, \mathrm{SXT})$. Interpretation of the results namely sensitive (S), intermediary resistant (I) and resistant (R) were made in accordance to the standard measurement of inhibitory zones in millimeter $(\mathrm{mm})$.

\subsubsection{Multiple Antibiotic Resistances (MAR) and Inhibition Resistance Index (ARI) of Test Isolates}

The antibiotic susceptibility patterns obtained from the standard disc diffusion procedure were used to calculate the MAR and ARI index for total number of isolates as follow:

$$
\mathrm{ARI}=y / n x
$$

where, $y$ is the number of resistant isolates, $n$ is the number of isolates and $x$ is the number of antibiotics [34] and

$$
\text { MAR index }=a / b
$$

where, $a$ is the number of antibiotics to which the isolates are resistant and $b$ is the total number of antibiotics exposed. A MAR value $\geq 0.2$ indicates that antibiotics are ineffective.

\subsubsection{Antimicrobial Assay}

The antimicrobial activity of algal flavonoid extracts was performed in vitro using the "hole-plate diffusion method" [35] at a concentration of $2000 \mu \mathrm{g} / \mathrm{ml}$. Each test isolate strain was maintained in cryocare bacterial preservation (cryobeads) stored at $-70^{\circ} \mathrm{C}$ and was recovered for testing by growth in MuellerHinton (M-H) broth (Oxiod, England) for $24 \mathrm{~h}$ at $37^{\circ} \mathrm{C}$ before testing. The inoculums suspension contains approximately $1.5 \times 10^{8} \mathrm{CFU} / \mathrm{mL}$ of bacteria. Each extract was placed into wells of $8 \mathrm{~mm}$ diameter. The plates were kept for $1 \mathrm{~h}$ at $4^{\circ} \mathrm{C}$ for allowing better diffusion of the extract into the agar. Subsequently, plates were incubated at $37^{\circ} \mathrm{C}$ for $18 \mathrm{~h}$. Methanol was used as a negative control. Diameters of inhibition zones (DIZ) were measured in $\mathrm{mm}$ and the results were recorded as the mean of triplicate experiments.

\subsubsection{Determination of Minimum Inhibitory Concentration (MIC)}

The MIC was defined as the lowest concentration that completely inhibited the growth for $24 \mathrm{~h}$. The MIC for the flavonoids extracts was determined by the macrodilution agar method. In the macrodilution agar method, a two-fold serial dilution of the flavonoids extracts was prepared in sterile freshly prepared Mueller-Hinton (M-H) broth used as diluents to achieve a decreasing concentration ranging from 500 to $20 \mu \mathrm{g} / \mathrm{ml}$. Sterile cork borer of $8.0 \mathrm{~mm}$ diameter was used to bore well in the pre-solidified Mueller-Hinton (M-H) plates and $150 \mu$ volume of each dilution was added aseptically into the wells made in $\mathrm{M}-\mathrm{H}$ plates in triplicate that had bacteria seeded with the standardized inoculum $\left(1.5 \times 10^{8} \mathrm{CFU} /\right.$ 
$\mathrm{ml})$. All the test plates were incubated at $37^{\circ} \mathrm{C}$ and were observed for the growth after $24 \mathrm{hr}$ [36].

\subsubsection{Determination of Minimum Bactericidal Concentration (MBC)}

The content of the MIC tubes and the content of the preceding tubes in the serial dilutions (2MIC, 3MIC and 4MIC) were subcultured into the MH broth. All bacterial plates were inoculated at $37^{\circ} \mathrm{C}$ for 24 hours after which they were examined. $\mathrm{MBC}$ was the lowest concentration that completely inhibited bacterial growth. To confirm the results of $\mathrm{MBC}, 1 \mathrm{ml}$ of the experimental suspensions was resubcultured in the M-H broth which were incubated at $37^{\circ} \mathrm{C}$ for $18-24 \mathrm{~h}$.

\subsection{Determination of Total Flavonoid Content}

Total flavonoid content was estimated according to [37]. $1 \mathrm{ml}$ of algal extract $(0.1 \mathrm{~g} / \mathrm{ml})$ was diluted with $4 \mathrm{ml}$ of water and was mixed with $0.3 \mathrm{ml}$ of $\mathrm{NaNO}_{2}$ $(5 \% \mathrm{w} / \mathrm{v})$. After $5 \mathrm{~min}, 0.3 \mathrm{ml}$ of $\mathrm{AlCl}_{3}(10 \% \mathrm{w} / \mathrm{v})$ was added followed by the addition of $2 \mathrm{ml}$ of $\mathrm{NaOH}(1 \mathrm{M})$ six minutes later. The reaction volume was increased up to $10 \mathrm{ml}$ by adding $2.4 \mathrm{ml}$ distilled water and the sample was incubated at room temperature (RT) for $15 \mathrm{~min}$. The absorbance was measured at $510 \mathrm{~nm}$ using spectrophotometer (Jenway Model 6405). The assay was performed in triplicate, and the flavonoids content was determined by interpolating the absorbance of the samples against a calibration curve constructed with rutin standard ( 1.25 to $20 \mathrm{mg} / \mathrm{ml})$ and expressed as milligrams of rutin equivalent per gram of extract (mg RE/g).

\subsection{Determination of Proanthocyanidin Content}

Total proanthocyanidin content was determined according to Li's method [38]; $0.5 \mathrm{~mL}$ of the flavonoids extracts $(4 \mathrm{mg} / \mathrm{ml})$ was added to $3 \mathrm{~mL}$ of $4 \%(\mathrm{w} / \mathrm{v})$ vanillin in methanol and $1.5 \mathrm{~mL}$ of $35 \% \mathrm{HCl}$ and then incubated at RT for $15 \mathrm{~min}$ in dark place. After which, absorbance was recorded at $500 \mathrm{~nm}$ by UV/visible spectrophotometer. Results were expressed as $\mathrm{mg}$ catechin equivalents per gram (mg CE/g of the extract) for each sample.

\subsection{Statistical Analysis}

Data were expressed as means \pm standard deviations (SD) of triplicate determinations. All statistical analyses were carried out using SPSS V.16 (Statistical Program for Social Sciences, SPSS Corporation, Chicago, IL). Statistical differences between extract activities were determined using ANOVA followed by Least Significant Difference (LSD) testing. Differences were considered statistically significant when $P<0.05$. The Pearsons correlation analysis was performed between antibacterial activity, total flavonoids and proanthocyanidin contents.

\section{Results}

Phytochemical screening of $C$. compressa and $P$. pavonica extracts showed the presence of most important phytoconstituents (results not shown). Flavanoids 
were presented in noticeable amounts in both $C$. compressa and $P$. pavonica.

The high content of flavonoids in the investigated algae, drawn our interest toward application of the recently adopted microwave procedure for the efficient extraction of these phytochemicals.

\subsection{Antibiotic Sensitivity Test of Bacteria}

A total of 17 isolates were obtained from milk, dairy products, meat and meat products. Based on standard microbiological techniques and 16S rDNA gene sequence, the isolates were identified as Staphylococcus aureus subsp. aureus (5 isolates), Bacillus cereus (3 isolates), Bacillus pumilus (1 isolates), Salmonella enterica subsp. enteric (4 isolates) and Enterohaemorrhagic Escherichia coli $\mathrm{O} 157$ (EHEC O157) (4 isolates) [31].

The 16S rDNA gene sequences of isolates are deposited at Libyan GenBank under accession numbers as $S$. aureus 122 (S1), S. aureus 128 (S2), S. aureus 287 (S3), S. aureus 125 (S4); $S$ aureus 283 (S5), B. cereus 4 (B1), B. cereus 16 (B2), B. cereus 72 (B3), B. pumilus 124 (B4), S. enterica 17 (Sal 1), S. enterica 18 (Sal 2), S. enterica 19 (Sal 3), S. enterica 29 (Sal 4), EHEC O157 57 (E1), EHEC O157 55 (E2), EHEC O157 52 (E3), EHEC O157 49 (E4).

\section{Antibiotic Sensitivity Patterns of Pathogenic Isolates}

Susceptibility tests were conducted with 24 antibiotics against the tested isolates. The antibiotic profile for each pathogenic bacterium was determined using 24 commercial antibiotic discs (Table 1 and Table 2). Over all the isolates were resistant to at least 7 different antibiotics, showing that all isolates were multi-drug resistant. S. enterica isolates: $S$. enterica $17 ;$ S. enterica $18 ; S$. enterica $19 ;$ S. enterica 29 were resistant to 14,22, 13 and 10 antibiotics used respectively, EHEC O157 isolates: EHEC O157 57 and EHE O157 52 were resistance to 13 antibiotics while EHEC O157 55 and EHEC O157 49 were resistant to 18 and 15 antibiotics respectively. Among 9 Gram positive isolates, $S$. aureus. $S$. aureus 122; $S$. aureus 128 , and $S$. aureus 125 were resistant to 5, 11, 10 respectively while $S$ aureus 283 and $S$. aureus 287 were resistance to 12 antibiotics, results showed that all $S$. aureus tested were methicillin resistant $S$. aureus (MRSA) and Bacillus cereus. $B$. cereus $4, B$. cereus 16 ; and $B$. cereus 72 and $B$. pumilus 124 were resistance to 10 , 9, 18 and 7 antibiotics respectively (Table 1 and Table 2).

The MAR index is the ratio of number of antibiotics ineffective against the organisms to the total number of antibiotics used [39]. The MAR index values of the tested organisms were reported in Table 3 and Table 4. The MAR index of isolated bacteria was greater than 0.2 , which indicates that most tested antibiotics are ineffective. The results indicated that Gram negative isolates showed significantly greater resistance and higher MAR indices $(0.63-0.96)$ than Gram positive isolates, with MAR index ranged from 0.38 - 0.83. In addition, the highest ARI value 0.19 was calculated for $S$. enterica, followed by 0.18 and 0.15 for EHEC O157 and B. cereus. In comparison, the lowest ARI value 0.11 was obtained by $S$. aureus (Table 1 and Table 2). 
Table 1. Antibiotic susceptibility results of multidrug resistant Gram-positive bacteria.

\begin{tabular}{|c|c|c|c|c|c|c|c|c|c|}
\hline \multirow{3}{*}{ Antibiotics } & \multicolumn{9}{|c|}{ Bacterium } \\
\hline & \multicolumn{4}{|c|}{ B. cereus and B. pumilus } & \multicolumn{5}{|c|}{ S. aureus } \\
\hline & B1 & B2 & B3 & B4 & S1 & S2 & S3 & S4 & S5 \\
\hline AML & $\mathrm{R}$ & $\mathrm{R}$ & $\mathrm{R}$ & $\mathrm{R}$ & $\mathrm{R}$ & $\mathrm{R}$ & S & $\mathrm{R}$ & S \\
\hline $\mathrm{AMC}$ & $\mathrm{R}$ & $\mathrm{R}$ & $\mathrm{R}$ & $S$ & S & S & $S$ & S & $S$ \\
\hline AMP & $\mathrm{R}$ & $\mathrm{R}$ & $\mathrm{R}$ & $\mathrm{R}$ & $\mathrm{R}$ & S & S & $\mathrm{R}$ & S \\
\hline B & $\mathrm{R}$ & $\mathrm{R}$ & $\mathrm{R}$ & $\mathrm{R}$ & I & S & S & I & S \\
\hline$P$ & $\mathrm{R}$ & $\mathrm{R}$ & $\mathrm{R}$ & $\mathrm{R}$ & $\mathrm{R}$ & I & S & $\mathrm{R}$ & S \\
\hline ME & $\mathrm{R}$ & $\mathrm{R}$ & $\mathrm{R}$ & $S$ & $\mathrm{R}$ & $\mathrm{R}$ & $\mathrm{R}$ & $\mathrm{R}$ & $\mathrm{R}$ \\
\hline $\mathrm{E}$ & I & I & $\mathrm{R}$ & $S$ & I & $\mathrm{R}$ & $\mathrm{R}$ & I & $\mathrm{R}$ \\
\hline $\mathrm{CN}$ & S & S & $\mathrm{R}$ & $S$ & $S$ & S & $\mathrm{R}$ & S & $\mathrm{R}$ \\
\hline K & S & I & $\mathrm{R}$ & $S$ & S & S & $\mathrm{R}$ & S & $\mathrm{R}$ \\
\hline MY & $\mathrm{R}$ & $\mathrm{R}$ & $\mathrm{R}$ & $\mathrm{R}$ & S & I & $\mathrm{R}$ & $S$ & $\mathrm{R}$ \\
\hline TOB & S & S & $\mathrm{R}$ & S & S & S & $\mathrm{R}$ & S & $\mathrm{R}$ \\
\hline VA & S & S & I & S & S & $S$ & I & I & I \\
\hline LEV & S & S & S & $S$ & S & S & S & I & S \\
\hline DA & I & I & $\mathrm{R}$ & $\mathrm{R}$ & S & $\mathrm{R}$ & $\mathrm{R}$ & $\mathrm{R}$ & $\mathrm{R}$ \\
\hline CTX & $\mathrm{R}$ & $\mathrm{R}$ & $\mathrm{R}$ & $\mathrm{R}$ & $\mathrm{R}$ & $\mathrm{R}$ & $\mathrm{R}$ & $\mathrm{R}$ & $\mathrm{R}$ \\
\hline DO & S & S & I & $S$ & S & S & $\mathrm{R}$ & S & $\mathrm{R}$ \\
\hline CIP & I & S & S & $S$ & I & S & S & I & S \\
\hline OB & $\mathrm{R}$ & $\mathrm{R}$ & $\mathrm{R}$ & I & I & $\mathrm{R}$ & $\mathrm{R}$ & $\mathrm{R}$ & $\mathrm{R}$ \\
\hline $\mathrm{F}$ & S & S & S & S & I & $\mathrm{R}$ & S & $\mathrm{R}$ & S \\
\hline OT & I & I & $\mathrm{R}$ & S & $S$ & $\mathrm{R}$ & $\mathrm{R}$ & $\mathrm{R}$ & $\mathrm{R}$ \\
\hline$S$ & $S$ & I & $\mathrm{R}$ & I & $S$ & $\mathrm{R}$ & S & I & $S$ \\
\hline $\mathrm{TE}$ & S & $S$ & $\mathrm{R}$ & $S$ & $S$ & $\mathrm{R}$ & $\mathrm{R}$ & S & $\mathrm{R}$ \\
\hline $\mathrm{C}$ & S & I & S & S & S & $\mathrm{R}$ & $S$ & $\mathrm{R}$ & S \\
\hline SXT & $\mathrm{R}$ & I & $\mathrm{R}$ & $S$ & S & $\mathrm{R}$ & S & $\mathrm{R}$ & S \\
\hline MAR Index & 0.58 & 0.67 & 0.83 & 0.38 & 0.41 & 0.58 & 0.54 & 0.71 & 0.58 \\
\hline ARI & \multicolumn{4}{|c|}{0.08} & & & 0.03 & & \\
\hline
\end{tabular}

R: Resistant; S: Sensitive; I: Intermediate; MAR index: Multi drug resistance; Antibiotics ( $\mu$ g/disc), AML: Amoxycillin 10; AMC: Amoxycillin/clavulanic acid 30; AMP: Ampicillin 10; B: Bacitracin 10; P: Penicillin 10; ME: Methicillin 5; E: Erythromycin 15; CN: Gentamycin 10; K: Kanmycin 30; MY: Lincomycin 10; TOB: Tobramycin 10; VA: Vancomycin 30; LEV: Levofloxacin 5; DA: Clindamycin 2; CTX: Cefotaime 30; DO: Doxycycline 30; CIP: Ciprofloxacin 5; OB: Cloxacillin 5; F: Nitrofurantoin 300; OT: Oxytetracyclin 30; S: Streptomycin 10; TE: Tetracycline 30; C: Chloramphenicol 30; SXT: Sulphamethoxazole/Trimethoprim 25. 
Table 2. Antibiotic susceptibility results of multidrug resistant Gram-negative bacteria.

\begin{tabular}{|c|c|c|c|c|c|c|c|c|}
\hline \multirow{3}{*}{ Antibiotics } & \multicolumn{8}{|c|}{ Bacterium } \\
\hline & \multicolumn{4}{|c|}{ EHEC O157 } & \multicolumn{4}{|c|}{ S. enterica } \\
\hline & E1 & $\mathrm{E} 2$ & E3 & E4 & Sal 1 & Sal 2 & Sal 3 & Sal 4 \\
\hline AML & $\mathrm{R}$ & $\mathrm{R}$ & $\mathrm{R}$ & S & $\mathrm{R}$ & $\mathrm{R}$ & $\mathrm{R}$ & I \\
\hline AMC & S & S & S & $\mathrm{R}$ & S & $\mathrm{R}$ & I & I \\
\hline AMP & $\mathrm{R}$ & $\mathrm{R}$ & $\mathrm{R}$ & $\mathrm{R}$ & S & $\mathrm{R}$ & I & S \\
\hline B & $\mathrm{R}$ & $\mathrm{R}$ & $\mathrm{R}$ & $\mathrm{R}$ & $\mathrm{R}$ & $\mathrm{R}$ & $\mathrm{R}$ & $\mathrm{R}$ \\
\hline $\mathbf{P}$ & $\mathrm{R}$ & $\mathrm{R}$ & $\mathrm{R}$ & $\mathrm{R}$ & $\mathrm{R}$ & $\mathrm{R}$ & $\mathrm{R}$ & I \\
\hline ME & S & $\mathrm{R}$ & $\mathrm{R}$ & $\mathrm{R}$ & $\mathrm{R}$ & $\mathrm{R}$ & $\mathrm{R}$ & I \\
\hline E & $\mathrm{R}$ & $\mathrm{R}$ & $\mathrm{R}$ & $\mathrm{R}$ & $\mathrm{R}$ & $\mathrm{R}$ & $\mathrm{R}$ & $\mathrm{R}$ \\
\hline $\mathrm{CN}$ & $\mathrm{R}$ & S & $\mathrm{R}$ & S & I & $\mathrm{R}$ & S & S \\
\hline $\mathrm{K}$ & I & $S$ & I & I & I & $\mathrm{R}$ & I & $S$ \\
\hline MY & $\mathrm{R}$ & $\mathrm{R}$ & $\mathrm{R}$ & $\mathrm{R}$ & $\mathrm{R}$ & $\mathrm{R}$ & $\mathrm{R}$ & $\mathrm{R}$ \\
\hline тов & $\mathrm{R}$ & I & $\mathrm{R}$ & I & $\mathrm{R}$ & $\mathrm{R}$ & S & S \\
\hline VA & $\mathrm{R}$ & $\mathrm{R}$ & $\mathrm{R}$ & $\mathrm{R}$ & $\mathrm{R}$ & $\mathrm{R}$ & $\mathrm{R}$ & $\mathrm{R}$ \\
\hline LEV & S & S & S & $\mathrm{R}$ & S & $\mathrm{R}$ & S & S \\
\hline $\mathrm{DA}$ & $\mathrm{R}$ & $\mathrm{R}$ & $\mathrm{R}$ & $\mathrm{R}$ & $\mathrm{R}$ & $\mathrm{R}$ & $\mathrm{R}$ & $\mathrm{R}$ \\
\hline CTX & I & I & I & I & S & I & I & I \\
\hline DO & $\mathrm{R}$ & S & $\mathrm{R}$ & S & $\mathrm{R}$ & $\mathrm{R}$ & $\mathrm{R}$ & $\mathrm{R}$ \\
\hline CIP & S & S & $\mathrm{R}$ & $\mathrm{R}$ & S & $\mathrm{R}$ & S & $S$ \\
\hline OB & $\mathrm{R}$ & $\mathrm{R}$ & $\mathrm{R}$ & $\mathrm{R}$ & $\mathrm{R}$ & $\mathrm{R}$ & $\mathrm{R}$ & $\mathrm{R}$ \\
\hline $\mathrm{F}$ & I & $S$ & I & S & S & S & I & $S$ \\
\hline OT & $\mathrm{R}$ & $\mathrm{R}$ & $\mathrm{R}$ & $\mathrm{R}$ & $\mathrm{R}$ & $\mathrm{R}$ & $\mathrm{R}$ & $\mathrm{R}$ \\
\hline$S$ & $\mathrm{R}$ & $\mathrm{R}$ & $\mathrm{R}$ & S & $\mathrm{R}$ & $\mathrm{R}$ & $\mathrm{R}$ & $\mathrm{R}$ \\
\hline $\mathrm{TE}$ & $\mathrm{R}$ & $\mathrm{R}$ & $\mathrm{R}$ & S & $\mathrm{R}$ & $\mathrm{R}$ & $\mathrm{R}$ & $\mathrm{R}$ \\
\hline $\mathrm{C}$ & S & $S$ & S & $S$ & S & $\mathrm{R}$ & S & $S$ \\
\hline SXT & S & S & $\mathrm{R}$ & S & S & $\mathrm{R}$ & S & $S$ \\
\hline IndexRAM & 0.75 & 0.63 & 0.88 & 0.67 & 0.63 & 0.75 & 0.96 & 0.67 \\
\hline ARI & \multicolumn{4}{|c|}{0.11} & \multicolumn{4}{|c|}{0.14} \\
\hline
\end{tabular}

R: Resistant; S: Sensitive; I: Intermediate; MAR index: Multi drug resistance; Antibiotics ( $\mu \mathrm{g} / \mathrm{disc})$, AML: Amoxycillin 10; AMC: Amoxycillin/clavulanic acid 30; AMP: Ampicillin 10; B: Bacitracin 10; P: Penicillin 10; ME: Methicillin 5; E: Erythromycin 15; CN: Gentamycin 10; K: Kanmycin 30; MY: Lincomycin 10; TOB: Tobramycin 10; VA: Vancomycin 30; LEV: Levofloxacin 5; DA: Clindamycin 2; CTX: Cefotaime 30; DO: Doxycycline 30; CIP: Ciprofloxacin 5; OB: Cloxacillin 5; F: Nitrofurantoin 300; OT: Oxytetracyclin 30; S: Streptomycin 10; TE: Tetracycline 30; C: Chloramphenicol 30; SXT: Sulphamethoxazole/Trimethoprim 25.

(Table 3 and Table 4) represent the antibacterial screening of the flavonoids extracted by MW, on Gram negative and Gram positive isolates. The results showed that $C$. compressa extract exhibited better and stronger antibacterial activities against 14 tested isolates with inhibition zones diameter ranged from 14 - 
Table 3. In vitro antimicrobial activity of the algal flavonoids extracts against Gram positive bacteria isolated from food products. $S$. aureus (5 isolates), B. cereus (3 isolates), and B. pumilus (1 isolate).

\begin{tabular}{cccc}
\hline & C. compressa & P. pavonica & \\
\cline { 2 - 3 } & DIZ $(\mathrm{mm})$ & MAR Index \\
\hline S1 & S. aureus isolates & & \\
S2 & $18.5 \pm 1.5^{\mathrm{c}}$ & $13.5 \pm 1.5^{\mathrm{b}}$ & 0 \\
S3 & $14 \pm 1^{\mathrm{d}}$ & $11.5 \pm 0.5^{\mathrm{c}}$ & 0 \\
S4 & $20.5 \pm 0.5^{\mathrm{b}}$ & $11.5 \pm 0.5^{\mathrm{c}}$ & 0 \\
S5 & - & - & 1 \\
ARI & - & - & 1 \\
& & 0.41 & \\
B1 & $B$. cereus isolates & & 0.5 \\
B2 & $22 \pm 2^{\mathrm{a}}$ & - & 0 \\
B3 & $20.5 \pm 0.5^{\mathrm{b}}$ & $16.5 \pm 0.5^{\mathrm{a}}$ & 0.5 \\
B4 & $17.5 \pm 0.5^{\mathrm{c}}$ & - & 1 \\
ARI & - & - & 0.5 \\
\hline
\end{tabular}

S1: $S$. aureus 122; S2: $S$. aureus 128; S3: S. aureus 287; S4: $S$. aureus 125 ; S5: $S$ aureus 283; B1: B. cereus 4; B2: B. cereus 16 ; B3: B. cereus 72 ; B4: B. pumilus 124 . Different letters indicate statistically significant differences between groups $(\mathrm{P}<0.05)$.

Table 4. In vitro antimicrobial activity of the algal flavonoids extracts against Gram negative bacteria isolated from food products. $S$. enterica (4 isolates) and EHEC O157 (4 isolates).

\begin{tabular}{cccc}
\hline & C. compressa & P. pavonica & \\
\cline { 2 - 3 } Bacterium & DIZ $(\mathrm{mm})$ & MIZ $(\mathrm{mm})$ & \\
& S. enterica isolates & & \\
Sal 1 & $31 \pm 1^{\mathrm{a}}$ & $27.5 \pm 0.5^{\mathrm{a}}$ & 0 \\
Sal 2 & $17.5 \pm 0.5^{\mathrm{c}}$ & - & 0.5 \\
Sal 3 & $17 \pm 1^{\mathrm{c}}$ & - & 0.5 \\
Sal 4 & $24.5 \pm 0.5^{\mathrm{b}}$ & $14.5 \pm 0.5^{\mathrm{b}}$ & 0 \\
ARI & & & \\
& & & \\
E1 & EHEC O157 isolates & - & 0.5 \\
E2 & $17 \pm 0^{\mathrm{c}}$ & - & 0.5 \\
E3 & $16.5 \pm 1.5^{\mathrm{c}}$ & - & 0.5 \\
E4 & $15 \pm 0^{\mathrm{d}}$ & & 0.5 \\
ARI & $16 \pm 0^{\mathrm{c}}$ & & \\
\hline
\end{tabular}

Data are expressed as the mean \pm standard deviation (SD) of three replicates. Sal 1: S. enterica 17; Sal 2: $S$. enterica 18; Sal 3: S. enterica 19; Sal 4: $S$. enterica 29; E1: EHEC O157 57; E2: EHEC O157 55; E3: EHEC O157 52; E4: EHEC O157 49. Different letters indicate statistically significant differences between groups (P $<0.05)$. 
$22 \mathrm{~mm}$ compared to $P$. pavonica extract which was observed positive effect against 9 isolates with low inhibition zone ranged from $11-16.5 \mathrm{~mm}$.

The highest activity was recorded with $C$. compressa extract against $S$. aureus 287 , and $B$. cereus 4 with zones of inhibition 20.5 and $22 \mathrm{~mm}$ respectively $(P<$ $0.05)$. Moderate activity was obtained against $S$. aureus $122, B$. cereus 16 and $B$. cereus 72 with zones of inhibition 18.5, 20.5 and 17.5 respectively. Weak activity was obtained against $S$. aureus 128 with zones of inhibition of $14 \mathrm{~mm}$ (Table 3 ). In comparison, flavonoids extracted from $P$. pavonica exhibited the highest activity against B2 with zone of inhibition $16 \mathrm{~mm}$ and significant weak activity against $S$. aureus $122, S$. aureus 128 and $S$. aureus 287 with zones of inhibition $13.5,11.5$ and $11.5 \mathrm{~mm}(P<0.05)$ (Table 3$)$.

Table 4 showed the antibacterial activity of the flavonoids extract of $C$. compressa against all tested Gram negative isolates in which zones of inhibition varied from 15 to $31 \mathrm{~mm}$ while $P$. pavonica showed lesser or no activity with zone inhibition diameter (14.5 and $27 \mathrm{~mm})$. The highest significant zones of inhibition was observed in $C$. compressa extract $(31 \pm 1 \mathrm{~mm})$ against $S$. enterica 17 ( $P$ $<0.05)$ followed by $S$. enterica $29(24 \mathrm{~mm})$. Also it was active against $S$. enterica 18, S. enterica 19 and EHEC 015757 zones of inhibition (17 mm) followed by EHEC O157 55, EHEC O157 49 (16 mm). In addition, C. compressa extract recorded the lowest activity against EHEC O157 52 (15 mm) (Table 4). In comparison, $P$. pavonica extract was active against $S$. enterica $17(14,5)$ and S. enterica $29(27 \mathrm{~mm})$ and the rest of isolates were resistant.

The MAR and ARI indices of the tested extracts were reported in Table 3 and Table 4. Unlike tested antibiotics, most isolates exhibited susceptibility to flavonoids extracted from algae with an average MAR index of $0-0.5$ which indicates that tested algal extracts are effective (Table 5 and Table 6). As shown in Table 5 and Table 6, $S$. aureus 122, $S$. aureus 128, $S$. aureus 287, B. cereus $16, S$. enterica 17 , and $S$. enterica 29 isolates with very low MAR value (0.0) were found to be susceptible to both extracts, in contrast $S$. aureus 125, $S$ aureus 283 and $B$. pumilus 124 isolates showed significantly high resistance with higher MAR value (1). Over all, the results indicated that: B. cereus S. enterica and EHEC O157 isolates showed greater resistance with higher ARI indices (0.5) than $S$. aureus isolates with a value ARI index of 0.41 (Table 3 and Table 4).

\subsection{Minimal Inhibitory/Bactericidal Concentrations (MICs/MBCs) of Active Extracts}

The minimal inhibitory concentration (MIC) of flavonoids extracted from $C$. compressa and $P$. pavonica were determined for various tested organisms. The MICs ranged from $31.25 \mu \mathrm{g} / \mathrm{mL}$ to $125 \mu \mathrm{g} / \mathrm{mL}$ and $62.5 \mu \mathrm{g} / \mathrm{mL}$ to $500 \mu \mathrm{g} / \mathrm{mL}$, respectively. The MICs and MBCs of the extracts are presented in Figure 2 and Figure 3.

The flavonoids extract of $C$. compressa had the lowest MIC value, $31.25 \mu \mathrm{g} /$ $\mathrm{ml}$ and the lowest $\mathrm{MBC}$ value $62.5 \mu \mathrm{g} / \mathrm{ml}$ against $S$. aureus 122 and $S$. enterica 17; MIC value of $62.5 \mu \mathrm{g} / \mathrm{ml}$ and $\mathrm{MBC}$ value of $125 \mu \mathrm{g} / \mathrm{ml}$ against $B$. cereus 4 
Table 5. MBC/MIC ratio for tested bacterial strains against flavonoids algal extracts.

\begin{tabular}{|c|c|c|}
\hline & C. compressa & P. pavonica \\
\hline \multicolumn{3}{|c|}{ MBC/MIC } \\
\hline \multicolumn{3}{|c|}{$S$. aureus isolates } \\
\hline S1 & 2 & 2 \\
\hline S2 & 2 & 2 \\
\hline S3 & 4 & 3 \\
\hline \multicolumn{3}{|c|}{ B. cereus isolates } \\
\hline B1 & 2 & - \\
\hline B2 & 3 & 2 \\
\hline \multirow[t]{2}{*}{ B3 } & 2 & - \\
\hline & S. enterica isolates & \\
\hline Sal 1 & 2 & 2 \\
\hline Sal 2 & 4 & - \\
\hline Sal 3 & 2 & - \\
\hline \multirow[t]{2}{*}{ Sal 4} & 4 & 3 \\
\hline & EHEC 0157 isolates & \\
\hline E1 & 4 & - \\
\hline E2 & 4 & - \\
\hline E3 & 4 & - \\
\hline $\mathrm{E} 4$ & 4 & - \\
\hline
\end{tabular}

S1: S. aureus 122; S2: S. aureus 128; S3: S. aureus 287; S4: S. aureus 125; S5: S. aureus 283 ; B1: B. cereus 4; B2: B. cereus 16; B3: B. cereus 72; B4: B. pumilus 124; Sal 1: S. enterica 17; Sal 2: S. enterica 18; Sal 3: S. enterica 19; Sal 4: S. enterica 29; E1: EHEC O157 57; E2: EHEC O157 55; E3: EHEC O157 52; E4: EHEC O157 49.

Table 6. Flavonoid, and Proanthocaynidin content in flavonoids extracted from C. compressa and $P$. pavonica.

\begin{tabular}{ccc}
\hline Algae & TFC $^{*}$ & Proanthocyanidin $^{* *}$ \\
\hline C. compressa & $110.92 \pm 11.38^{\mathrm{a}}$ & $0.24 \pm 0.0^{\mathrm{a}}$ \\
$P$. pavonica & $70.08 \pm 2.42^{\mathrm{b}}$ & $0.072 \pm 0.0^{\mathrm{b}}$ \\
\hline
\end{tabular}

Each value is represented as mean $\pm \mathrm{SD}(\mathrm{n}=3)$. Means with the same letter are not significantly different at $P<0.05$. ${ }^{*}$ : Expressed as mg Rutin/g, ${ }^{* *}$ Expressed as mg Catechin/g.

and $B$. cereus 72 , MIC value of $125 \mu \mathrm{g} / \mathrm{ml}$ and $\mathrm{MBC}$ value of $250 \mu \mathrm{g} / \mathrm{ml}$ against $S$. aureus 128 and S. enterica 19, MIC value of $62.5 \mu \mathrm{g} / \mathrm{ml}$ and MBC value of 187.5 $\mu \mathrm{g} / \mathrm{ml}$ against $B$. cereus 16 , while MIC value of $62.5 \mu \mathrm{g} / \mathrm{ml}$ and $\mathrm{MBC}$ value of 250 $\mu \mathrm{g} / \mathrm{ml}$ against $S$. enterica 29. On the other hand, the highest MIC value of 125 $\mu \mathrm{g} / \mathrm{ml}$, and the highest $\mathrm{MBC}$ value of $500 \mu \mathrm{g} / \mathrm{ml}$ due to $C$. compressa extract were noted for EHEC O157 57, EHEC O157 55 and S. enterica 18 (Figure 2 and Figure 3). 


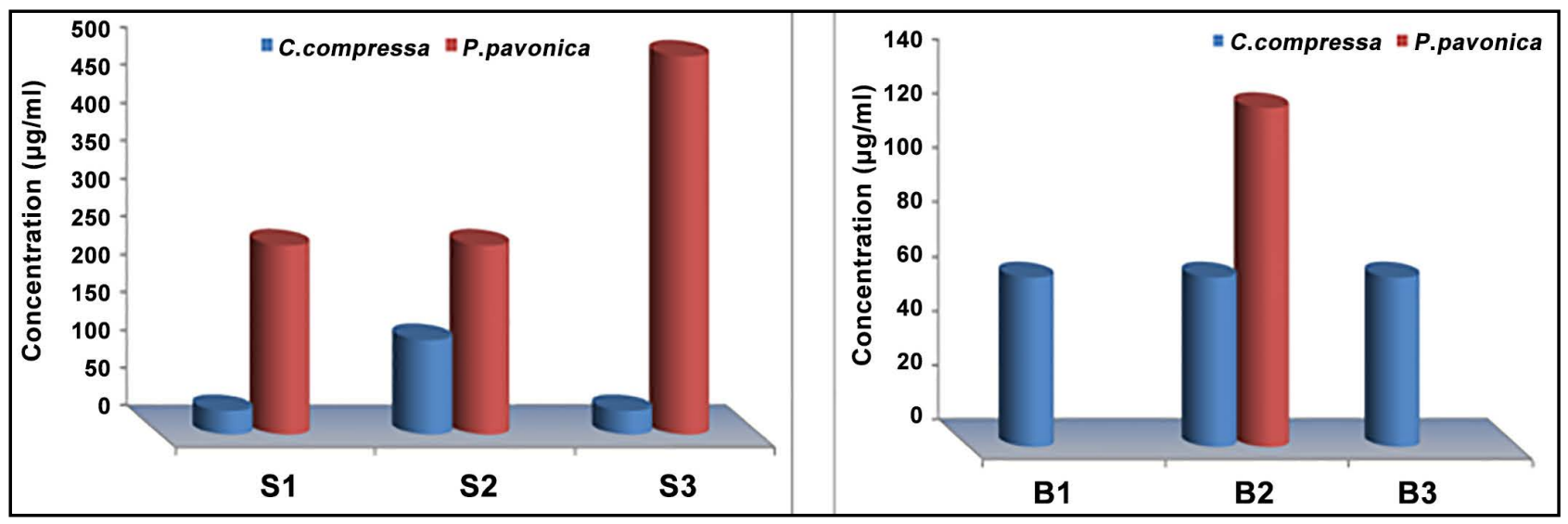

(a)

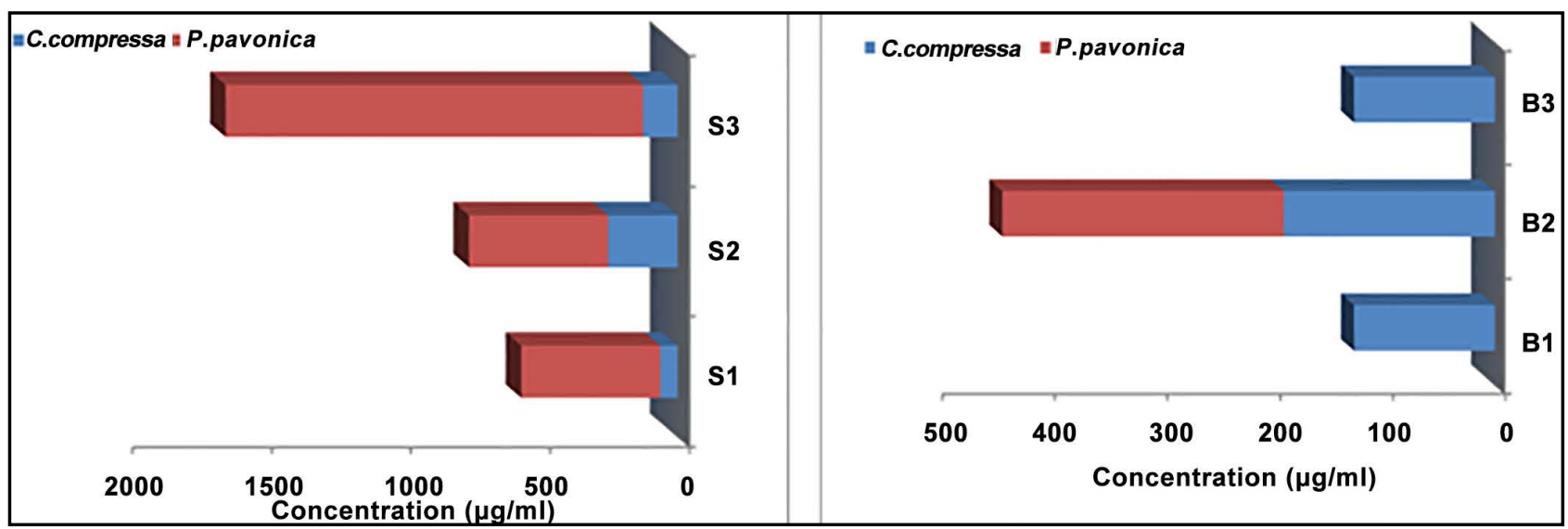

(b)

Figure 2. Minimal inhibitory concentration (MIC) (a) and minimal bactericidal (MBC) (b) of the algal extracts against Gram positive bacteria (S1: S. aureus 122; S2: S. aureus 128; S3: S. aureus 287, B1: B. cereus 4; B2: B. cereus 16; B3: B. cereus 72).

The flavonoids extract of $P$. pavonica showed the lowest MIC value of 62.5 $\mu \mathrm{g} / \mathrm{ml}$ and the lowest MBC value of $125 \mu \mathrm{g} / \mathrm{ml}$ against $S$. enterica 17 ; MIC value of $125 \mu \mathrm{g} / \mathrm{ml}$ and $\mathrm{MBC}$ value of $250 \mu \mathrm{g} / \mathrm{ml}$ was recorded against $B$. cereus 16 ; MIC value of $250 \mu \mathrm{g} / \mathrm{ml}$ and MBC value of $500 \mu \mathrm{g} / \mathrm{ml}$ was noted against $S$. aureus 122 and $S$. aureus 128; MIC value of $250 \mu \mathrm{g} / \mathrm{ml}$ and MBC value of $750 \mu \mathrm{g} / \mathrm{ml}$ were recorded against $S$. enterica 29 while the highest MIC value of $500 \mu \mathrm{g} / \mathrm{ml}$, and the highest MBC value of $1500 \mu \mathrm{g} / \mathrm{ml}$ was obtained against $S$. aureus 287 (Figure 2 and Figure 3).

Flavonoids extracted from $C$. compressa also displayed the best spectrum of bactericidal effect with a ratio $\mathrm{MBC} / \mathrm{MIC} \leq 4$ obtained on all tested bacterial strains (Table 5). Although an antibacterial activity (MIC) was detected in the flavonoids extracts of two algae against all 11 tested bacterial isolates, the MBC values (bactericidal activity) showed a different pattern of activity from that of MIC (Table 5).

\subsection{Flavanoids and Proanthocyanidin Contents}

Flavonoids including proanthocyanidin were determined in tested algae. Their 


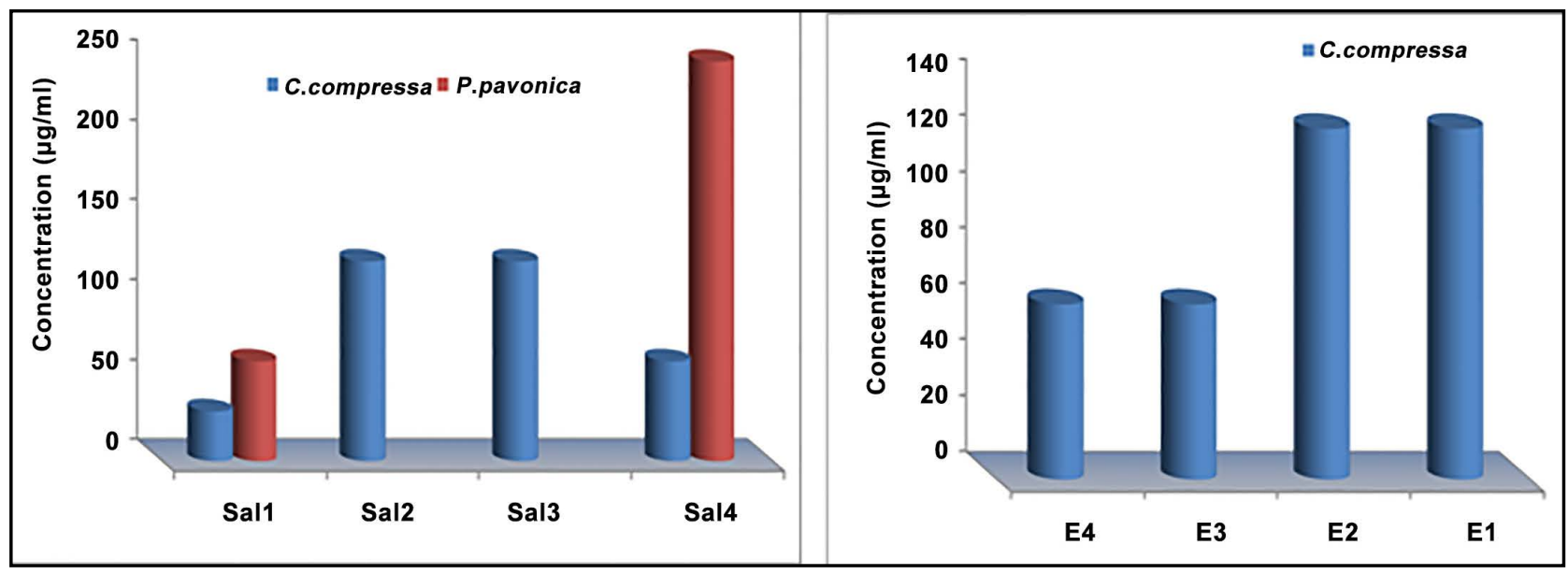

(a)

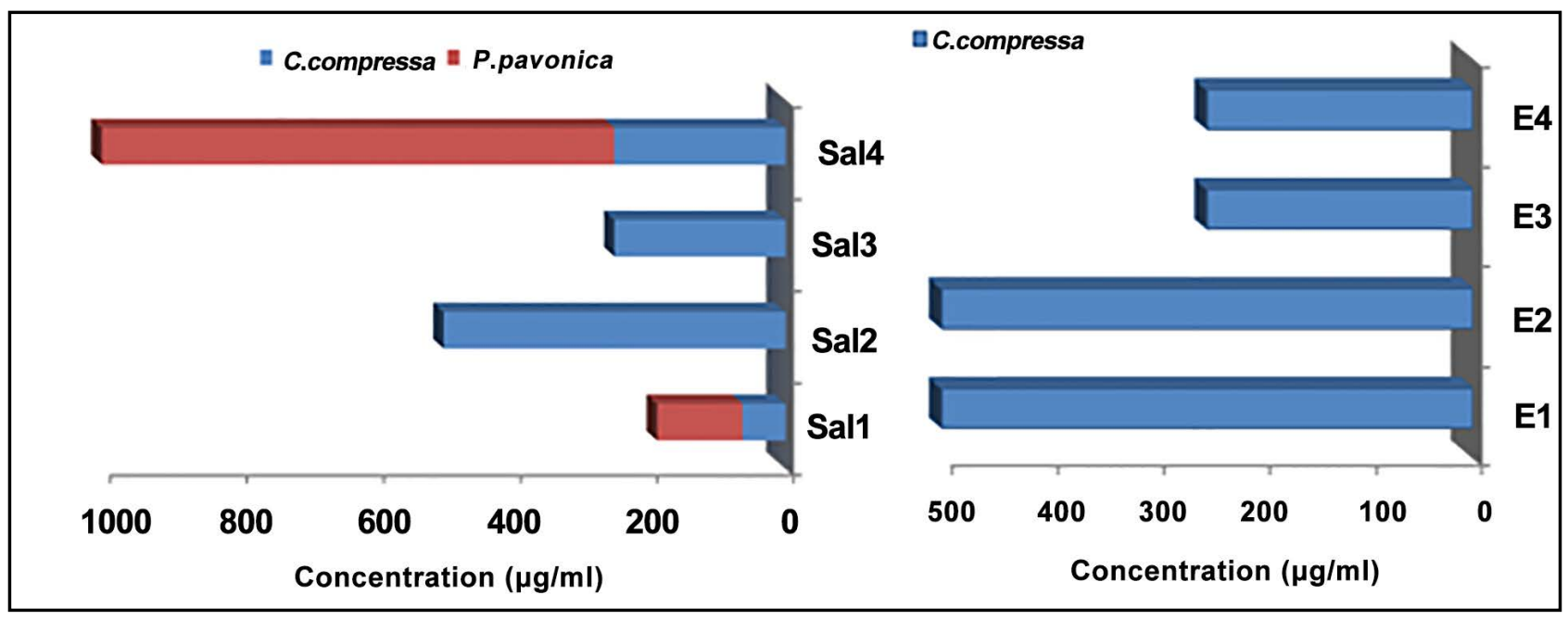

(b)

Figure 3. Minimal inhibitory concentration (MIC) (a) and minimal bactericidal (MBC) (b) of the algal flavonoids extracts against Gram negative bacteria (Sal 1: S. enterica 17; Sal 2: S. enterica 18; Sal 3: S. enterica 19; Sal 4: S. enterica 29; E1: EHEC O157 57; E2: EHEC O157 55; E3: EHEC O157 52; E4: EHECO157 49).

levels in C. compressa extracts were remarkably higher than their counterpart in $P$. pavonica $(P<0.05)$. The amount of flavonoids in $C$. compressa was 110.92 $\mathrm{mg} / \mathrm{g}$ Rutin equivalent while in $P$. pavonica was $70.08 \mathrm{mg} / \mathrm{g}$ Rutin equivalent (Table 6).

\subsection{Correlation between the Values of Antibacterial Activities of Flavonoids and Proanthocyanidin Contents}

In order to examine possible association between antibacterial activity and flavonoids and proanthocyanidin content in algae extracts, correlation coefficient $\left(R^{2}\right)$ was evaluated.

There were no correlations between the level of flavonoids with antibacterial activity against $B$. cereus isolates and $S$. enterica isolates whereas no correlation was observed between proanthocyanidin content and antibacterial activity against EHEC O157 isolates. In addition, a positive correlation was found between each 
of flavonoids and proanthocyanidin contents in algae extracts with antibacterial activity against $S$. aureus isolates and EHECO157 isolates $\left(\mathrm{R}^{2}=0.646,0.99\right.$ respectively).

\section{Discussion}

Antimicrobial resistance is a growing problem and a public health threat. To overcome infections caused by multidrug-resistant strains, new classes of antimicrobials should be developed. Algae may offer an alternative source of antimicrobial agents with significant activities against pathogens with less risks of adverse effect encountered with synthetic antibiotics. Moreover, a number of antibiotics have lost their effectiveness due to the abuse of their applications and the evolution of resistant strains of microorganisms [40].

Marine organisms including macroalgae are a rich source of structurally novel biologically active metabolites [2]. Therefore, active constituents of various algae extracts could be potential bioactive compounds of interest in the pharmaceutical industry [1]. In the present study, phytochemical screening of the seaweeds showed the presence of most important phytoconstituents. Flavonoids were present in C. compressa in higher amounts than those found in P. pavonica. Since the preliminary screenings of the algal extract have shown the presence of flavonoids in appreciable amounts [41], this fraction was chosen to be evaluated for antibacterial activity.

Flavonoids belong to the large group of secondary metabolites called polyphenols with variable phenolic structures and are found to be the most important natural substances responsible for their bioactivity. Flavonoids have been reported to exhibit a wide range of bioactivity including antioxidants, antibacterial, antiviral, anticancer, anti-inflammatory, anti-allergic and also as potential therapeutic agents against a wide variety of diseases [6] [7] [8].

It has been stated that antibacterial activity depends on algal species, the efficiency of the extraction method, and the resistance of the tested bacteria [42]. Many studies revealed that brown algae has higher amount of flavonoids compared with green and red algae [43] [44]. Hence, in this study, brown algae, namely $C$. compressa and $P$. pavonica, were selected to evaluate their flavonoids contents and study their antibacterial activity against isolated multidrug resistant (MDR) bacteria.

The extraction method plays an important role in the overall effect of natural antimicrobial products. Active compounds have been extracted and purified using different extraction methods including ultrasonication assisted extraction and soxhlet extraction [16] [17]. However, these methods require enormous amounts of solvents, time consuming, expensive and environmentally unfriendly. Therefore, microwave was used to assisted flavonoids extraction which was approved to have high efficiency for extraction [45]. The flavonoids yields obtained with microwave assisted extraction were far highly active than conventionally extracted ones [17]. Higher flavonoids yields per gram of algae material were obtained in microwave assisted extraction in both tested samples. The yield ob- 
tained from $C$. compressa was higher than that in $P$. pavonica, which was consistent with our previous findings [46].

Antibiotics provide the main basis for the therapy of bacterial infections. However, the high genetic variability of bacteria enables them to rapidly evade the action of antibiotics by developing antibiotic resistance. As resistance becomes more common, there becomes a greater need for alternative treatments. However, despite a push for new antibiotic therapies there has been a continued decline in the number of newly approved drugs [47] [48]. Our results showed that the isolates were resistant to at least 7 different antibiotics, which indicates that all isolates are multi-drug resistant [49]. Gram negative isolates were highly resistant to antibiotics and showed significantly greater resistance with higher MAR indices (0.63 - 0.96) and ARI index (0.18 - 0.19). In comparison Gram positive isolates including MRSA were more susceptible with lower MAR index ranged from $0.38-0.83$ and ARI index $(0.11-0.15)$. The isolates that have MAR index $\geq 0.2$ were considered as multidrug resistant [39]. Therefore, we aimed to analyze the flavonoids extracted from seaweeds for their use as new antibacterial agents against multidrug resistant bacteria which have been isolated from food products.

The antibacterial activity of crude extracts of $C$. compressa and $P$. pavonica are well known [21] [24] [50] [51]. However, no study has determined the antimicrobial activity of flavonoids extracted from brown algae so far. In the present study, flavonoid rich extract of $C$. compressa had the broadest inhibitor activities against the test isolates (highest inhibitor activity against $S$. enterica $17,31 \mathrm{~mm}$ DIZ, MIC, $31.25 \mu \mathrm{g} / \mathrm{ml}$, MBC $62.5 \mu \mathrm{g} / \mathrm{ml}$ ). In comparison flavonoids extracted from $P$. pavonica had weak effect on most tested isolates (most active against $S$. enterica 17, $27.5 \mathrm{~mm}$ DIZ, MIC, $62.5 \mu \mathrm{g} / \mathrm{ml}$, MBC, $125 \mu \mathrm{g} / \mathrm{ml})$. Among the tested bacterial strains, EHEC O157 isolates (a food borne pathogen) was found most sensitive against the $C$. compressa extracts with DIZ ranged from 15 to 17 mm. while $P$. pavonica showed no effect on all EHEC $\mathrm{O} 157$ isolates, which was in agreement with [16].

The minimum concentration necessary to kill an organism should be equal to or greater than the MIC for that microbe [52]. A sample is bactericidal when the ratio $\mathrm{MBC} / \mathrm{MIC} \leq 4$ and bacteriostatic when this ratio is $>4$ [53]. It therefore seems to be that antibacterial effects obtained with the flavonoids extracted from tested algae against susceptible isolates, proved to have bactericidal activity. Current results were in parallel with previous results which suggested that flavonoids are capable of bactericidal activity which resulting mostly from the impairment of the cell wall integrity and to cell agglutination [54].

The different rates of inhibition activities appear to be directly related to the qualitative and quantitative amount of the extracted flavonoids content in tested algae. The amount of flavonoids in C. compressa was $110.92 \mathrm{mg} / \mathrm{g}$ Rutin equivalent which was higher than that reported by [55]. The recorded antibacterial activity was shown to correlate with the total flavonoids and proanthocyanidin contents in the tested algal extracts with high correlation coefficient ( $r$ ) ranged 
from 0.293 to 0.995 . The antimicrobial properties of natural products have been attributed to its high flavonoids content and in particular the presence of the proanthocyanidin [8]. The present results showed that flavonoids rich extract of C. compressa exhibited a significant inhibitory activity against both Gram positive and negative bacteria which increased its value as an ideal or broad spectrum antibacterial for MDR microorganisms.

Our results are in agreement with several previous findings demonstrating greater activity of flavonoids extracts towards Gram-positive bacteria compared to Gram-negative bacteria [56]. The probable reason is the difference in the composition and permeability of their cell walls. The cell walls of Gram-positive bacteria are made of peptidoglycans and teichoic acids, while the outer membrane found in the Gram-negative cell wall is composed of structural lipopolysaccharides which render the cell wall impermeable to lipophilic solutes [57] [58].

To the best of our knowledge, there are no reports concerning the comparative antibacterial activity analysis for investigated flavonoids extracted from algae. However, many studies have been done on flavonoids extracted from plants [59] [60] [61]. It has been revealed that the antibacterial activities of natural products are related to structures and cellular membranes of tested bacteria by varied mechanisms via several events at a cellular level [62] [63]. Previous study showed a strong relationship between flavonoids structures due to the substitutions on the aromatic rings and antibacterial activity [64].

Flavonoids have proven to be antibacterial agents, especially the ones with hydrophobic substituent such as prenyl groups, alkylamino chains, alkyl chains, and nitrogen or oxygen containing heterocyclic moieties [65] [66]. Flavones have been widely investigated with respect to their antibacterial activity showed strong activities against both Gram negative bacteria (E. coli, S. typhimurium) and Gram positive bacteria ( $S$. epidermis, $S$. aureus). Another observation showed limited activities against Gram positive bacteria [67]. Proanthocyanidins also have been reported to be effective antibacterial agents against both sensitive and multi-drug resistant strains [68] [69].

The exact mode of action mechanism of natural antimicrobials is still not fully understood. However, different mechanisms for different antimicrobial groups have been reviewed [8], and concluded that, different versions of proposed mechanisms of action for antibacterial activity of flavonoids into three main mechanisms including inhibition of nucleic acid synthesis [70], inhibition of cytoplasmic membrane function [54], inhibition of energy metabolism by disturbing the exchange of nutrients and metabolites [71] in addition, inhibition of cell membrane synthesis and the aggregatory effect on whole bacterial cells was considered as possible mechanism [72].

\section{Conclusion}

This study concluded that the flavonoids isolated from Libyan algae showed antibacterial potentiality against multi-drug resistant Gram positive and negative 
bacterial isolates including MRSA. However, whether such extracts will act as effective antibacterial agents in vivo remain to be investigated and the study of mechanisms of actions is necessary prior to their application.

\section{Acknowledgements}

This study was partially supported by a grant provided by the Libyan Authority for Research, Science and Technology (LARST). Authors are grateful to Veronica Papini, a technician in Istituto Zooprofilattico Sperimentale della Lombardia e dell' Emilia Romagna, Brescia, Italy, who performed the partial sequecing of $16 \mathrm{~S}$ rDNA.

\section{Competing Interests}

Authors have declared that no competing interests exist.

\section{References}

[1] Rodrigues, E., Tilvi, S. and Naik, C.G. (2004) Antimicrobial Activity of Marine Organisms Collected off the Coast of East India. Journal of Experimental Marine Biology and Ecology, 309, 121-127. https://doi.org/10.1016/j.jembe.2004.03.010

[2] Cabrita, M., Vale, C. and Rauter, A. (2010) Halogenated Compounds from Marine Algae. Marine Drugs, 8, 2301-2317. https://doi.org/10.3390/md8082301

[3] Molinski, T.F., Dalisay, D.S., Lievens, S.L. and Saludes, J.P. (2009) Drug Development from Marine Natural Products. Nature Reviews Drug Discovery, 28, 69-85. https://doi.org/10.1038/nrd2487

[4] Mayer, A.M.S., Glaser, K.B., Cuevas, C., Jacobs, R.S., Kem, W., Little, R.D., McIntosh, J.M., Newman, D.J., Potts, B.C. and Shuster, D.E. (2010) The Odyssey of Marine Pharmaceuticals: A Current Pipeline Perspective. Trends in Pharmacological Sciences, 31, 255-265. https://doi.org/10.1016/j.tips.2010.02.005

[5] Colla, L.M., Reinehr, C.O., Reichert, C.J. and Costa, A.V. (2007) Production of Biomass and Nutraceutical Compounds by Spirulina platensis under Different Temperature and Nitrogen Regimes. Bioresource Technology, 98, 1489-1493. https://doi.org/10.1016/j.biortech.2005.09.030

[6] Ross, J. and Kasum, C. (2002) Dietary Flavonoids: Bioavailability, Metabolic Effects and Safety. Annual Review of Nutrition, 22, 19-34. https://doi.org/10.1146/annurev.nutr.22.111401.144957

[7] Williams, R.J., Spencer, J.P. and Rice-Evans, C. (2004) Flavonoids: Antioxidants or Signalling Molecules. Free Radical Biology \& Medicine, 36, 838-849. https://doi.org/10.1016/j.freeradbiomed.2004.01.001

[8] Cushnie, T.P.T. and Lamb, A.J. (2005) Antimicrobial Activity of Flavonoids. International Journal of Antimicrobial Agents, 26, 343-356. https://doi.org/10.1016/j.ijantimicag.2005.09.002

[9] Markham, K.R. (1988) Distribution of Flavonoids in the Lower Plants and Its Evolutionary Significance. In: Harborne, J.B., Ed., The Flavonoids, Advances in Research Since 1980, Academic Press, New York, 427-468.

[10] Wang, C., Wei, M., Su, J. and Zeng, L. (1998) Research on the Chemical Constituents of Acanthophora spicifera in the South China. Chinese Journal of Magnetic Resonance, 15, 237-242.

[11] Zeng, L.M., Wang, C.-J., et al. (2001) Flavonoids from the Red Alga Acanthophora 
spicifera. Chinese Journal of Chemistry, 19, 1097-1100.

https://doi.org/10.1002/cjoc.20010191116

[12] Sabina, H. and Aliya, R. (2009) Seaweed as a New Source of Flavone, Scutellarein 4'-Methyl ether. Pakistan Journal of Botany, 41, 1927-1930.

[13] Masaru, K., Toyoda, M., Teshima, R., Sasada, J., Hayashi, T., Artsawa, M., Shimizu, M., Morita, N., Inoue, S. and Saito, Y. (1994) In Vitro Antiallergic Activity of Flavonoids in Histamine Release Assay Using Rat Basophilic Leukemia (RBL-2H3) Cells. Journal of the Food Hygienic Society of Japan, 35, 497-503. https://doi.org/10.3358/shokueishi.35.497

[14] Shan, X.U., Li, L., Liqun, Z., Zhuo, L., Lili, Q., Qi, C. and Changfen, X. (2006) Reversale Effect of 4'-Methylether-Scutellarein on Multidrug Resistance of Human Choriocarcinoma JAR/VP 16 Cell Line. Progress in Biochemistry and Biophysics, 33, 1061-1073.

[15] Bicchi, C., Drigo, S. and Rubiolo, P. (2000) Influence of Fiber Coating in Headspace Solid-Phase Microextraction-Gas Chromatographic Analysis of Aromatic and Medicinal Plants. Journal of Chromatography A, 892, 469-485.

https://doi.org/10.1016/S0021-9673(00)00231-4

[16] Tuney, I., Cadirci, B.H., Unal, D. and Sukatar, A. (2010) Antimicrobial Activities of the Extracts of Marine Algae from the Coast of Urla (Izmir, Turkey). Turkish Journal of Biology, 30, 171-175.

[17] Tiwari, P., Kumar, B., Kaur, M., Kaur, G. and Kaur, H. (2011) Phytochemical Screening and Extraction: A Review. Internationale Pharmaceutica Sciencia, 1, 98106.

[18] Kaufmann, B. and Christen, P. (2002) Recent Extraction Techniques for Natural Products: Microwave-Assisted Extraction and Pressurised Solvent Extraction. Phytochemical Analysis, 13, 105-113. https://doi.org/10.1002/pca.631

[19] Ioannou, I. and Ghoul, M. (2012) Biological Activities and Effects of Food Processing on Flavonoids as Phenolic Antioxidants. In: Petre, M., Ed., Advances in Applied Biotechnology, Chapter 5, InTech, 101-124.

[20] Palaniappan, K. and Holley, R.A. (2010) Use of Natural Antimicrobials to Increase Antibiotic Susceptibility of Drug Resistant Bacteria. International Journal of Food Microbiology, 140, 164-168. https://doi.org/10.1016/j.ijfoodmicro.2010.04.001

[21] Bansemir, A., Blume, M., Schroder, S. and Lindequist, U. (2006) Screening of Cultivated Seaweeds for Antibacterial Activity against Fish Pathogenic Bacteria. Aquaculture, 252, 79-84. https://doi.org/10.1016/j.aquaculture.2005.11.051

[22] Kuda, T., Kunii, T., Goto, H., Suzuki, T. and Yano, T. (2007) Varieties of Antioxidant and Antibacterial Properties of Ecklonia stolonifera and Ecklonia kurome Products Harvested and Processed in the Noto Peninsula, Japan. Food Chemistry, 103, 900-905. https://doi.org/10.1016/j.foodchem.2006.09.042

[23] Shanmughapriya, S., Manilal, A., Sujith, S., Selvin, J., Kiran, G. and Seenivasan, K. (2008) Antimicrobial Activity of Seaweeds Extracts against Multi Resistant Pathogens. Annals of Microbiology, 58, 535-541. https://doi.org/10.1007/BF03175554

[24] Alghazeer, R., Whida, F., Abduelrhman, E., Gammoudi, F. and Azwai, S. (2013) Screening of Antibacterial Activity in Marine Green, Red and Brown Macroalgae from the Western Coast of Libya. Natural Science, 5, 7-14. https://doi.org/10.4236/ns.2013.51002

[25] Cowan, M.M. (1999) Plant Products as Antimicrobial Agents. Clinical Microbiology Reviews, 12, 564-582.

[26] Yee, Y.K. and Koo, M.W.L. (2000) Anti-Helicobacter Pylori Activity of Chinese 
Tea: In Vitro Study. Alimentary Pharmacology and Therapeutics, 14, 635-638. https://doi.org/10.1046/j.1365-2036.2000.00747.x

[27] Odebiyi, A. and Sofowora, A.E. (1990) Phytochemical Screening of Nigerian Medicinal Plants. Part III. Lloydia, 41, 234-246.

[28] Quan, P.T., Hang, T.V., Ha, N.H., De, N.X. and Tuyen, T.N. (2006) MicrowaveAssisted Extraction of Polyphenols from Fresh Tea Shoot. Science and Technology Development, 9, 69-75.

[29] Naas, T., Oxacelay, C. and Nordmann, P. (2007) Identification of CTX-M-Type Extended-Spectrum-Beta-Lactamase Genes Using Real-Time PCR and Pyrosequencing. Antimicrobial Agents and Chemotherapy, 51, 223-230. https://doi.org/10.1128/AAC.00611-06

[30] Garabaj, A.M., Naas, H.T., Azwai, S.M. and Gammoudi, F.T. (2007) Incidence of Staphylococci with Special Reference to Staphylococcus aureus in Two Types of Locally Processed Soft Cheese in Tripoli, Libya. Benha Veterinary Medical Journal, 18, 139-147.

[31] Azwai, S., Alfallani, E., Abdulaziz, A., Abolghait, S., Garbaj, A., Naas, H., Moawad, A., Gammoudi, F., Rayes, H., Barbieri, I. and Eldaghayes, I. (2016) Isolation and Molecular Identification of Vibrio spp. by Sequencing of 16S rDNA from Seafood, Meat and Meat Products in Libya. Open Veterinary Journal, 6, 36-42.

https://doi.org/10.4314/ovj.v6i1.6

[32] CLSI (2012) Methods for Dilution Antimicrobial Susceptibility Tests for Bacteria That Grows Aerobically. Approved Standard, 9th Edition, CLSI Document MO7A9, Clinical and Laboratory Standards Institute, Wayne.

[33] NCCLS (National Committee for Clinical Laboratory Standard) (2003) Methods for Dilution Antimicrobial Susceptibility Tests for Bacteria That Grow Aerobically. Approved Standard, NCCLS DocumentM7-A6, Wayne.

[34] Hinton, M. and Linton, A. (1983) Antibacterial Drug Resistance among Escherichia coli Isolated from Calves Fed Milk Substitute. Veterinary Record, 112, 567-568. https://doi.org/10.1136/vr.112.24.567

[35] Saravanakumar, A., Amutha, P., Gandhimathi, R. and Dhanapal, R. (2009) Study on Phytochemical Profile and Antiepileptic Activity of Inner Bark of Guettarda speciosa (L.). Iranian Journal of Pharmacology \&Therapeutics, 8, 73-76.

[36] Pundir, R.K. and Bishnoi, S. (2011) Antimicrobial Activity of Mitragyna parvifolia Barks and Butea monosperma Leaves Extracts against Human Pathogenic Microbial Strains. International Journal of Drug Development \& Research, 3, 141-147.

[37] Zhishen, J., Mengcheng, T. and Jianming, W. (1999) The Determination of Flavonoid Contents in Mulberry and Their Scavenging Effects on Superoxide Radicals. Food Chemistry, 64, 555-559. https://doi.org/10.1016/S0308-8146(98)00102-2

[38] Li, Y., Guo, C., Yang, J., Wei, J., Xu, J. and Cheng, S. (2006) Evaluation of Antioxidant Properties of Pomegranate peel Extract in Comparison with Pomegranate pulp Extract. Food Chemistry, 96, 254-260. https://doi.org/10.1016/j.foodchem.2005.02.033

[39] Krumperman, P.H. (1985) Multiple Antibiotic Indexing of E. coli to Identify High Risk Sources of Fecal Contamination of Foods. Applied and Environmental Microbiology, 46, 165-170.

[40] Lushniak, B.D. (2014) Antibiotic Resistance: A Public Health Crisis. Public Health Report, 129, 314-316.

[41] Cox, S., Abu-Ghannam, N. and Gupta, S. (2010) An Assessment of the Antioxidant and Antimicrobial Activity of Six Species of Edible Irish Seaweeds. International 
Food Research Journal, 17, 205-220.

[42] Seenivasan, R., Indu, H., Archana, G. and Geetha, S. (2010) The Antibacterial Activity of Some Marine Algae from South East Coast of India. Journal of Pharmacy Research, 3, 1907-1912.

[43] Yumiko, Y.S., Yaa-Pei, H. and Takeshi, S. (2003) Distribution of Flavonoids and Related Compounds from Seaweeds in Japan. Journal of Tokyo University of Fisheries, 89, 1-6.

[44] Alghazeer, R., Ibrahim, A., Abdulaziz, A. and Abouamer, K. (2016) In-Vitro Antioxidant Activity of Five Selected Species of Libyan Algae. International Journal of Medicine and Pharmaceutical Research, 4, 1-9.

[45] Tatke, P. and Jaiswal, Y. (2011) An Overview of Microwave Assisted Extraction and Its Applications in Herbal Drug Research. Research Journal of Medicinal Plant, 5, 21-31. https://doi.org/10.3923/rjmp.2011.21.31

[46] Alghazeer, R., Whida, F., Al-Najjar, A., Majdoob, H. and Al-Mazoghi, E. (2008) Assessment of Antioxidant Activity and Phenolic Content of Some Marine Algae from the Libyan Coast. Ain Shams Science Bulletin, 46, 67-78.

[47] Bachi, B.B. (2002) Resistance Mechanisms of Gram Positive Bacteria. International Journal of Medical Microbiology, 292, 27-35. https://doi.org/10.1078/1438-4221-00185

[48] Nagi, A.A.H., Mashan, N.I., Shamsudin, M.N., Mohamad, H. and Vairappan, C.S. (2010) Antibacterial Activity of Marine Source Extracts against Multidrug Resistance Organisms. American Journal of Pharmacology and Toxicology, 5, 95-102. https://doi.org/10.3844/ajptsp.2010.95.102

[49] Didic, S., Suskovic, J. and Kos, B. (2008) Antibiotic Resistance Mechanisms in Bacteria: Biochemical and Genetic Aspects. Food Technology and Biotechnology, 46, 11-21.

[50] Hellio, C., De La Broise, D., Dufosse, L., Le Gal, Y. and Bourgougnon, N. (2001) Inhibition of Marine Bacteria by Extracts of Macroalgae: Potential Use for Environmentally Friendly Antifouling Paints. Marine Environmental Research, 52, 231-247. https://doi.org/10.1016/S0141-1136(01)00092-7

[51] Dubber, D. and Harder, T. (2008) Extracts of Ceramium rubrum, Mastocarpus stellatus and Laminaria digitata Inhibit Growth of Marine and Fish Pathogenic Bacteria at Ecologically Realistic Concentrations. Aquaculture, 274, 196-200.

https://doi.org/10.1016/j.aquaculture.2007.11.029

[52] Nakamura, C.V., Ueda-Nakamura, T., Bando, E., Melo, A.F., Cortez, D.A. and Dias Filho, B.P. (1999) Antibacterial Activity of Ocimum gratissimum L. Essential Oil. Memórias do Instituto Oswaldo Cruz, 94, 675-678. https://doi.org/10.1590/S0074-02761999000500022

[53] Noumedem, J., Mihasan, M., Lacmata, S., Stefan, M., Kuiate, J. and Kuete, V. (2013) Antibacterial Activities of the Methanol Extracts of Ten Cameroonian Vegetables against Gram-Negative Multidrug-Resistant Bacteria. BMC Complementary and Alternative Medicine, 17, 13-26. https://doi.org/10.1186/1472-6882-13-26

[54] Cushnie, T.P.T. and Lamb, A.J. (2005) Detection of Galangin-Induced Cytoplasmic Membrane Damage in Staphylococcus aureus by Measuring Potassium Loss. Journal of Ethnopharmacology, 101, 243-248. https://doi.org/10.1016/j.jep.2005.04.014

[55] Marijana, K., Branislav, R. and Tatjana, S. (2015) Biological Potential of Marine Macroalgae of the Genus Cystoseira. Acta Biologica Hungarica, 66, 374-384. https://doi.org/10.1556/018.66.2015.4.2

[56] Mandalari, G., Bennett, R.N., Bisignano, G., Trombetta, D., Saija, A., Faulds, C.B., 
Gasson, M.J. and Narbad, A. (2007) Antimicrobial Activity of Flavonoids Extracted from Bergamot (Citrus bergamia Risso) Peel. A Byproduct of the Essential Oil Industry. Journal of Applied Microbiology, 103, 2056-2064. https://doi.org/10.1111/j.1365-2672.2007.03456.x

[57] Heijenoort, J. (2001) Formation of the Glycan Chains in the Synthesis of Bacterial Peptidoglycan. Glycobiology, 11, 25-36. https://doi.org/10.1093/glycob/11.3.25R

[58] Kosanić, M., Ranković, B. and Stanojković, T. (2012) Antioxidant, Antimicrobial and Anticancer Activity of 3 Umbilicaria Species. Journal of Food Science, 77, 2025. https://doi.org/10.1111/j.1750-3841.2011.02459.x

[59] Rahman, M. and Moon, S. (2007) Antimicrobial Phenolic Derivatives from Dendranthema zawadskii var. latilobum kitamura (Asteraceae). Archives of Pharmacal Research, 30, 1374-1379. https://doi.org/10.1007/BF02977359

[60] Ayaz, F., HayIrlIoglu-Ayaz, S., Alpay-Karaoglu, S., Gruz, J., Valentová, K., Ulrichová, J. and Strnad, M. (2008) Phenolic Acid Contents of Kale (Brassica oleraceae L. var. acephala DC.) Extracts and Their Antioxidant and Antibacterial Activities. Food Chemistry, 107, 19-25. https://doi.org/10.1016/j.foodchem.2007.07.003

[61] Rudi, H., Syahida, A., Aspollah, S.M., Yunus, S. and Ehsan, O. (2011) Flavonoid Analyses and Antimicrobial Activity of Various Parts of Phaleria macrocarpa (Scheff.) Boerl Fruit. International Journal of Molecular Sciences, 12, 3422-3431. https://doi.org/10.3390/ijms12063422

[62] Lou, Z., Wang, H., Zhu, S., Ma, C. and Wang, Z. (2011) Antibacterial Activity and Mechanism of Action of Chlorogenic Acid. Journal of Food Science, 76, 398-403. https://doi.org/10.1111/j.1750-3841.2011.02213.x

[63] Farzaneh, V. and Carvalho, I.S. (2015) A Review of the Health Benefit Potentials of Herbal Plant Infusions and Their Mechanisms of Actions. Industrial Crops and Products, 65, 247-258. https://doi.org/10.1016/j.indcrop.2014.10.057

[64] Xie, Y., Yang, W., Tang, F., Chen, X. and Ren, L. (2015) Antibacterial Activities of Flavonoids: Structure-Activity Relationship and Mechanism. Current Medicinal Chemistry, 22, 132-149. https://doi.org/10.2174/0929867321666140916113443

[65] Prawat, U., Chairerk, O., Phupornprasert, U., Salae, A.W. and Tuntiwachwuttikul, P. (2013) Two New C-Benzylated Dihydrochalcone Derivatives from the Leaves of Melodorum siamensis. Planta Medica, 79, 83-86.

[66] Rashid, F., Mahmood, A., Ifzal, R. and Malik, A. (2013) Flavonoids of Prunus armeniaca and Their Antibacterial Studies. Journal of the Chemical Society of Pakistan, 35, 905-910.

[67] Sohn, H.Y., Son, K.H., Kwon, C.S., Kwon, G.S. and Kang, S.S. (2004) Antimicrobial and Cytotoxic Activity of 18 Prenylated Flavonoids Isolated from Medicinal Plants: Morus alba L., Morus mongolica Schneider, Broussnetia papyrifera (L.) Vent, Sophora flavescens Ait and Echinosophora koreensis Nakai. Phytomedicine, 11, 666672. https://doi.org/10.1016/j.phymed.2003.09.005

[68] Al-Habib, A., Al-Saleh, E., Safer, A.M. and Afzal, M. (2010) Bactericidal Effect of Grape Seed Extract on Methicillin-Resistant Staphylococcus aureus (MRSA). Journal of Toxicological Sciences, 35, 364-375. https://doi.org/10.2131/jts.35.357

[69] Gupta, A., Dwivedi, M., Mahdi, A., Nagana Gowda, G.A., Khetrapal, C. and Bhandari, M. (2012) Inhibition of Adherence of Multi-Drug Resistant E. coli by Proa Nthocyanidin. Urological Research, 40, 143-150. https://doi.org/10.1007/s00240-011-0398-2

[70] Ulanowska, K., Tkaczyk, A., Konopa, G. and Wegrzyn, G. (2006) Differential Antibacterial Activity of Genistein Arising from Global Inhibition of DNA, RNA and 
Protein Synthesis in some Bacterial Strains. Archives of Microbiology, 184, 271-278. https://doi.org/10.1007/s00203-005-0063-7

[71] Eumkeb, G. and Chukrathok, S. (2013) Synergistic Activity and Mechanism of Action of Ceftazidime and Apigenin Combination against Ceftazidime-Resistant Enterobacter cloacae. Phytomedicine, 20, 262-269.

https://doi.org/10.1016/j.phymed.2012.10.008

[72] Cushnie, T.P.T. and Lamb, A.J. (2011) Recent Advances in Understanding the Antibacterial Properties of Flavonoids. International Journal of Antimicrobial Agents, 38, 99-107. https://doi.org/10.1016/j.ijantimicag.2011.02.014

Submit or recommend next manuscript to SCIRP and we will provide best service for you:

Accepting pre-submission inquiries through Email, Facebook, LinkedIn, Twitter, etc. A wide selection of journals (inclusive of 9 subjects, more than 200 journals) Providing 24-hour high-quality service User-friendly online submission system Fair and swift peer-review system Efficient typesetting and proofreading procedure Display of the result of downloads and visits, as well as the number of cited articles Maximum dissemination of your research work

Submit your manuscript at: http://papersubmission.scirp.org/

Or contact jbm@scirp.org 